\title{
Hematopoietic stem cells from peripheral blood the perspective of non-mobilized peripheral blood
}

\author{
Vassilios Katsares*, Zissis Paparidis, Eleni Nikolaidou, Anastasia Petsa, Iliana Karvounidou, \\ Karina-Alina Ardelean, Nikolaos Peroulis, Nikolaos Grigoriadis, John Grigoriadis
}

Biogenea-Cellgenea Ltd, Trade Centre "Plateia", Thessaloniki, Greece; *Corresponding Author: vkatsare@gmail.com

Received 1 February 2010; revised 21 February 2010; accepted 23 February 2010.

\begin{abstract}
The peripheral blood is a major source of hematopoietic stem cells. Almost for two decades the peripheral blood has been mobilized, in order to enhance the $\mathrm{CD} 34^{+}$concentration. The isolated stem cells from the mobilized peripheral blood are used as an alternative, or in addition to bone marrow derived stem cells. In this paper, a new perspective is being discussed; the use of non-mobilized peripheral blood as an alternative source for hematopoietic progenitor cells. The number of isolated hematopoietic stem cells is evaluated using flow cytometry. The viability can be evaluated using the trypan blue exclusion test, the flow cytometry or automated assays. The isolated hematopoietic stem cells could be used for ex vivo expansion either in static systems or in proper bioreactor systems, prior to cryopreservation and/or transplantation.
\end{abstract}

Keywords: Non-Mobilized Peripheral Blood; Hematopoietic Stem Cells; Ex Vivo Expansion

\section{INTRODUCTION}

Since the early 1990s, peripheral blood progenitor cells collected by apheresis have largely replaced bone marrow as a source of hematopoietic stem cells for autologous transplantation [1]. Peripheral blood cells produce more rapid hematopoietic recovery, thereby leading to reduced costs [2-5]. Furthermore, although follow-up is more limited in the PBSC group than in the BM group, no evidence was found that the use of PBSC was associated with an increased risk of chronic GVHD compared to results with BM [6].

\section{CHARACTERIZATION OF HEMATOPOIETIC STEM CELLS}

Hematopoietic stem cells are normally found in very limited numbers in the peripheral circulation (less than $0.1 \%$ of all nucleated cells). It is logical that progenitor cells circulate in the periphery, as this ensures an even distribution of hematopoiesis within the BM [7]. CD34 antigen expression is used as a surrogate marker for hematopoietic stem cells and enumeration of $\mathrm{CD} 34^{+}$cells has been used to quantify progenitor and stem cell content [8].

PBSCs represent a subpopulation of all $\mathrm{CD} 34^{+}$cells $\left(\mathrm{CD} 34^{+} / \mathrm{CD}^{-} 8^{-}\right)$found in the circulation [9]. CD34 ${ }^{+}$cell viability was measured by an established flow cytometric method [10]. The method is based on triple staining with anti-CD34-PE, anti-CD45-FITC, and the viability marker 7-actinomycin $\mathrm{D}$, and it allows the calculation of the absolute numbers of viable CD $34^{+}$cells. Recently, a new rapid and accurate method has been developed for the viability evaluation based on luminometry [11].

\section{CRYOPRESERVATION AND THAWING OF PBPCS}

PBPCs are usually harvested and stored in liquid $\mathrm{N}_{2}$ until reinfusion. Storage at this low temperature will block all enzymatic pathways and metabolism in the cell [12]. Cryopreservative(s) must be added to the PBSC before freezing in order to protect the cells. The concentration of the cryoprotectant and the rate at which the cells are frozen are the main factors governing the survival of the cells. Thereafter the cells are stored in liquid $\mathrm{N}_{2}$ [13]. Due to their different cell membrane composition and higher osmotic inactive volume, $\mathrm{CD} 34^{+}$cells are better protected from hypertonic shock and ice crystal formation and should be more resistant to cryopreservation damage than the remaining nucleated cell population [14].

A computer-controlled freezer is used for the cryopreservation. In order to ensure rate-controlled freezing an optimized program is developed and adjusted accordingly.

In controlled rate freezing, the concentrated stem cells are frozen down at a rate of $1-2^{0} \mathrm{C} / \mathrm{min}$ up to a tempera- 
ture point of about $-40^{\circ} \mathrm{C}$. Then, the freezing process down to a target of $-120^{\circ} \mathrm{C}$ is performed at a faster pace, about $3-5^{\circ} \mathrm{C} / \mathrm{min}$. For PBSCs the controlled rate freezing process is considered standard $[15,16]$, and was in different reports found to be superior to uncontrolled freezing approaches. This procedure is time consuming and requires staff with a specific expertise. Hence, the use of uncontrolled rate freezing in which the specimen is first cooled down to $-4^{\circ} \mathrm{C}$ and then directly deposited into a freezer at $-80^{\circ} \mathrm{C}$ or put into liquid phase nitrogen has been evaluated. Several reports [17-19] established that the uncontrolled method is safe and reveals comparable results to the controlled rate process for PBSCs. A controlled study performed by Perez-Oteyza et al. [20] showed that the controlled and uncontrolled rate freezing approach are comparable in terms of viability testing and that only a statistically significant decrease in the CFUGM clonality assay could be detected in the uncontrolled freezing situation. Recent studies suggested that uncontrolled freezing is also a viable approach for UCB stem cells [21,22].

As a cryoprotectant, a solution containing 50\% DMSO in HAES-steril ${ }^{\circledR} 10 \%$ is used. Prior to freezing, a part of pre-cooled cryosolution (with 50\% DMSO) is mixed with three parts of the buffy coat (pre-cooled), to achieve DMSO concentration of 5 or $10 \%$ in the final solution. Cryopreservation is then carried out in aliquots in cryogenic vials.

Current protocols for cryopreservation of PBPCs are usually based on the use of 10 percent DMSO in the freezing medium [23]. HPCs can be preserved with 5\% DMSO, and such autografts can be safely used for stem cell rescue even after long-term nitrogen storage [24].

Several techniques for the thawing procedure have been proposed. The standard method is warming in a water bath at $37^{\circ} \mathrm{C}$ until all ice crystals disappear [19]. A German study compared the thawing of cryopreserved units in a warm water bath with dry heat applied by gel pads at $37^{\circ} \mathrm{C}$. The viability and clonogenic potential were comparable, with a trend towards less infectious contamination in the dry method [25]. Different studies examined the preservation of function when thawed units were incubated at $0-37^{\circ} \mathrm{C}[19,26]$.

Akkök et al. [25] suggest that even simple singlewash DMSO depletion causes significant $\mathrm{CD} 34^{+}$cell loss. Despite a beneficial impact on the frequency of adverse effects during and after stem cell infusion, this time-consuming procedure caused a delayed PLT recovery and increased requirement for PLT transfusions. The CD $34^{+}$cell loss, however, was never critically low, that is, never lower than $2 \times 10^{6}$ per $\mathrm{kg}$. They concluded that single manual washing of autografts is a simple and safe procedure that decreases the frequency of adverse events during and after stem cell infusion. The procedure should be recommended especially for patients with an increased risk of serious toxicity, for example, patients with cardiac amyloidosis.

\section{THERAPEUTIC DOSES OF PBSC}

Typical doses of CD34 ${ }^{+}$stem cells used for PBSCs are $2 \times 10^{6}$ cells $/ \mathrm{kg}$ of recipient body weight or greater. Doses lower than this threshold is associated with prolonged cytopenias and increased early mortality [27]. The use of higher doses of $\mathrm{CD}_{3} 4^{+}$cells may lead to quicker engraftment, particularly when doses are greatly increased [28,29]. Platelet recovery appears to be more sensitive to $\mathrm{CD} 4^{+}$doses than neutrophil recovery [29]. Efforts to enrich PBSCT by ex-vivo CD34 ${ }^{+}$cell selection (positive selection) have resulted in increased rates of GVHD, possibly by altering the cytokine expression patterns of transplanted cells or changing lymphocyte subsets delivered with the graft [30].

Autologous stem cell grafting has been used with varying degrees of success in chronic myelogenous leukemia (CML) [31,32], acute leukemia [33], myelodysplasia [34], and multiple myeloma [35].

Niwa et al. [36] reported successful autologous peripheral blood stem cell transplantation with a doubleconditioning regimen for recurrent hepatoblastoma after liver transplantation.

Nevskaya et al. [37] with preliminary results suggested the feasibility of therapeutic angiogenesis by local implantation of $\mathrm{CD} 34^{+}$and MNC from PB for Systemic Sclerosis ischemic ulcers. Improved endothelial function, stimulatory effects on circulating endothelial precursors kinetics and augmentation of microcirculatory blood flow may contribute to therapeutic potential of the implanted cells.

\section{COST ANALYSIS}

The cost method involved two sets of data: a data set including patient-related or direct costs, and a data set including nonpatient-related or indirect costs [38]. The patient-related costs comprise the followings: 1) hospitalization and basic medical service, including medical and nursing staff; 2) pharmacy and blood products; 3) procedures such as operating theatre, leukapheresis and cryopreservation. On the other hand, the indirect costs comprise the clinical service department costs, for instance, radiology, clinical chemistry, pharmacy and the nonclinical service departments such as transportation, housekeeping and kitchen services.

A study by Mishra et al. [38] reported a cost analysis using mobilized peripheral blood at 2001 prices and the 
costs had been recalculated into US\$ by using the exchange rates of 1 st January 2001. The mean cost for the mobilization/cryopreservation phase per patient was US\$ 6544 (range 5114-7273). The mean cost of high dose chemotherapy followed by hospitalization was US\$ 25616 (13978-43277). This amounts to total running costs of US\$ 32160 (19092-50550). Taken together, staffing, medication and blood products contributed to $74 \%$ of total costs. On average, $53 \%$ of total costs comprised staff costs, ranging from 39 to $76 \%$. Personnel resources varied from one center to another, from US\$ 12608 to US\$ 26038 per patient. Pharmacy and blood products contributed 16 and $5 \%$, respectively, of the total costs.

A study by van Agthoven [39] documented total costs of PBSC transplantation at Euro 33742. The author applied a unit cost method where staff costs accounted for $42 \%$ of the transplant cost. This relatively large difference in staff costs between Van Agthoven and Mishra et $a l$. is notable, and may indicate there are cost variations between different countries, for example, related to wages. Van Agthoven [39] reported a remarkably low cost per patient for the stem cell harvesting and cryopreservation procedures, an average of $€ 4982$, and a blood component cost (during the induction chemotherapy regimen, harvesting and transplantation phase), respectively, of $€ 904$, $€ 376$ and $€ 1680$, a total of $€ 2960$.

In another study, Ghosh et al. [40] reported a PBSCT cost for patients with plasma cell leukemia that ranged from US\$ 20000 to US\$ 25000. The major part of the costs related to hospitalization, growth factors, blood products, collection and cryopreservation of PBSC.

Hopefully, the use of non mobilized peripheral blood could eliminate the cost, since there are no mobilization drugs and no any special equipment required.

\section{EX VIVO EXPANSION OF HSC}

The $\mathrm{CD} 4^{+}$surface antigen, which is a glycoprotein expressed on early progenitor cells is present on less than $0.1 \%$ of the mononuclear cells in peripheral blood [41]. Many studies have shown that the minimum acceptable dose of HPCs for successful transplantation ranges between $2-5 \times 10^{6} \mathrm{CD} 34^{+}$cells per $\mathrm{kg}$ of recipient weight [42]. Furthermore, transplantation of higher doses of CD $34^{+}$cells seems to improve haematopoietic recovery and overall survival $[43,44]$. To try and overcome the problem of low progenitor cell dose, ex vivo expansion of CB-derived cells has been attempted. The true test of this method is whether an expansion technology will be able to provide a reliable, reproducible increase in the number of progenitor cells available from a single unit of $\mathrm{CB}$, resulting in superior rates of engraftment and overall survival in adult patients. A significant hurdle of presently available methods for graft production is the ability to generate an expanded population of committed hematopoietic progenitor cells without compromising the numbers of less differentiated progenitor cells $\left(\mathrm{CD} 34^{+} \mathrm{CD}^{-} 8^{-}\right.$or $\mathrm{CD}_{3}{ }^{+} \mathrm{Lin}^{-}$cells), which are important functional hematopoietic repopulating cells [45].

In order to consistently achieve an adequate cell dose, the processing methods must minimize cell losses. Each additional manipulation of a cellular product potentially leads to further loss of cells. In most studies, CD $34^{+}$cell selection is done before initiating cell culture [46], but the $\mathrm{CD} 34^{+}$cell selection itself is associated with a substantial loss of progenitor cells. This cell loss, which may not be significant for smaller children, may become critical in reaching a suitable dose for transplant in older children and adults [47].

To achieve adequate cell doses, many researcher used different ex vivo expansion protocols, either the traditional way, or using a bioreactor system. Beshlawy et al. [48] used three cytokine combinations, i.e. cell factor alone, IL-3 alone, and both stem cell factor and IL-3. Interleukin-3 enhances the amplification of early and committed progenitor cells without impairing the long-term engraftment of stem cells [49].

Several investigators reported significantly decreased cell viability after cryopreservation [50-51] and attributed this to the effect of thawing and washing to remove the cryoprotectant. Laroche et al. [47] stated that thawing and washing result in loss of cells approaching 20\% when compared with pre-freeze counts, with the wash step responsible for nearly half of this cell loss. However, Beshlawy et al. [48], using umbilical cord blood derived hematopoietic stem cells, detected mean fold expansion of $6.64 \pm 3.34$ with stem cell factor alone, $7.38 \pm 2.86$ with both stem cell factor and IL-3, and $8.11 \pm 4.49$ with IL-3 alone after 2 days culture of the samples frozen for 2 weeks. There were no statistically significant differences in fold expansion between the 3 cytokine combinations before freezing and after 1 week and 2 weeks of freezing. They concluded that although preservation procedures could decrease the count and viability of cord blood HSCs, freezing does not impair their ex vivo expansion potential; however, it results in a significant loss of cell viability.

In a similar study, Moezzi et al. [51] used stem cell factor, IL-3, and thrombopoietin and reported levels of expansion of (4.2-4.7 fold) after 7 days of culture of samples cryopreserved for 1 month.

It was shown that a combination of early- and lateacting cytokines, including SCF, thrombopoietin (TPO), G-CSF and IL-3, resulted in only a marginal-fold expansion of late $\left(\mathrm{CD} 34^{+}\right)$and early $\left(\mathrm{CD} 34^{+} \mathrm{CD} 38^{-}\right)$progenitor 
cells, probably due the fact that the late-acting cytokines drive the cultures mainly toward accelerated differentiation $[52,53]$.

On the other hand, cultures with only early-acting cytokines (SCF, TPO, IL-6 and FLT-3 ligand) resulted in better and prolonged expansion of both late and early progenitors [54], which are important for short-term early trilineage engraftment [55-57].

Peled et al. [58] suggested that TEPA supports the self renewal division cycle without compromising differentiation capacity of hematopoietic stem cells.

A number of serum-free media have been used over the last few years with different results [59-62]. For obtaining sufficient numbers of progenitor cells for transplant, FCS [63] and autologous plasma [60,61] have been used in clinical expansion protocols. However, Lam et al. [61] suggested that, with the appropriate serum-free media and cytokines, FCS may be excluded in clinical expansions. On the other hand, human plasma, which may contain factors that promote cell maturation $[64,65]$ is thus unlikely to add significant value to the expansion.

It has been reported that MSC constitutively secrete various hematopoietic cytokines, among them stem cell factor (SCF), Flt-3 ligand (FL), thrombopoietin (TPO), leukemia-inhibiting factor (LIF), interleukin (IL)-6, IL-7, IL-8, IL-11, IL-12, IL-14, and IL-15 [66-68]. Addition of MSC as a feeder layer has been shown to improve expansion of cord blood HSC, inhibit their differentiation, and decrease their rate of apoptosis [66,69-71]. Li et al. [66] demonstrated that bone marrow MSC can increase human adult PBSC expansion as compared with culture in the presence of cytokine alone.

Conventional culture systems such as T-flasks and gas permeable blood bags are the most widely used devices for expanding hematopoietic cells. However, such static culture systems have several inherent limitations. Firstly, lack of mixing results in concentration gradients for dissolved oxygen (DO), $\mathrm{pH}$, cytokines and metabolites. Secondly, the environmental conditions in well-plate and T-flask are not readily monitored or controlled online. Thirdly, static systems require repeated changes of culture medium, which significantly increases the risk of contamination. Hence there is an urgent need for developing bioreactors for HSCs expansion, which overcomes the limitation of mass transport, keeps culture parameters constant and controls differentiation [72].

Several kinds of bioreactors have been applied in the field of HSCs expansion, including stirred tank bioreactor, fixed bed bioreactor and perfusion chamber [73-75]. It is known that hematopoietic cells are extremely sensitive to shear force, hence cells may suffer some physical damage under shear environment like in a stirred tank bioreactor and perfusion chambers [73]. In stirred tank bioreactor, agitation may affect cell surface marker expression, including cytokine receptors, which can have a profound effect on which cells expand and to what extent expansion occurs [73]. A condition with low shear but low concentration gradients is highly desirable for hematopoietic cell expansion [72].

Rotating wall vessel (RWV) bioreactor may provide a technical solution. The RWV bioreactor has several key characteristic features as follows [76]: firstly, fluid flow is near solid body and is laminar at most operating conditions, which avoids the large shear stresses associated with turbulent flow and allows introduction of controlled and nearly homogenous shear fields; secondly, the culture medium is gently mixed by rotation, avoiding the necessity for stirring vanes, which may damage cells by both local turbulence at their surface and the high flow rates created between the vessel walls and the vanes; thirdly, there is no headspace in the RWV bioreactor while in roller bottles, due to incomplete filling of the vessel, the air in the headspace creates turbulence and secondary bubble formation in the culture medium, which are both potent sources of extra shear and turbulence; finally, the RWV bioreactor supports coculture efficiently by bringing different cell types of different size and density together simply and efficiently. So by optimizing the geometry of the bioreactor and operational condition, it is possible to provide a uniform and low shear condition within the bioreactor. At the same time concentration gradient can be minimized.

RWV bioreactors have been used to simulate microgravity in space flight to study how microgravity affects the hematopoiesis of astronauts [77,78], to proliferate BM cells [79]. The RWV bioreactor can provide a 3D suspension culture environment and all hematopoietic cells are suspended in the culture medium effectively, which overcomes the concentration gradients in T-flasks and makes the utilization of cytokines more effective.

The National Aeronautics and Space Administration (NASA) developed two RWV bioreactors for tissue mass culture [80]. The slow turn lateral vessel (STLV) bioreactor has been used to culture several kinds of cells both on Earth and in space. The STLV was operated at 15-30 rpm on Earth and slower in space allowing a free-fall state, reducing the shear stress. The high aspect ratio vessel (HARV) bioreactor has a similar design, but the rotating speed can be slower than STLV. The NASA RWV systems have been used to study the effects of microgravity on murine HSC and evaluating the hematopoietic homeostasis during long space expeditions [81].

The elucidation of mechanisms governing self-renewal and differentiation of HSC is needed to control the in 
vitro expansion. Results from pilot clinical trials of transplants using expanded UCB-HSC have shown no adverse effects in the patients. However, more clinical trials must be conducted using expanded HSC for guarantying the safety [82]. Very recently, Delaney et al. (2010) claimed that when cord blood progenitors expanded ex vivo in the presence of Notch ligand we infused in a clinical setting after a myeloablative preparative regimen for stem cell transplantation, the time to neutrophil recovery was substantially shortened. This is the first instance of rapid engraftment derived form ex vivo expanded stem/progenitor cells in humans [83].

\section{AUTHORS' CONTRIBUTION}

All authors contributed substantially to this research. V.K., J.G., and N.G. designed research and collected the data; V.K., Z.P., A.P., E.N., I.K., and K.A.A. performed literature revision; V.K. analysed and interpreted data, and wrote the manuscript. All authors drafted the manuscript, revised it critically and approved it.

\section{REFERENCES}

[1] Champlin, R.E., Schmitz, N., Horowitz, M.M., Chapuis, B., Chopra, R., Cornelissen, J.J., Gale, R.P., Goldman, J.M., Loberiza, F.R., Hertenstein, B., Klein, J.P., Monstserrat, E., Zhang, M.J., Ringdeon, O., Tomany, S.C., Rowlings, P.A., Van Hoef, M.E. and Gratwohl, A. (2000) Blood stem cells compared with bone marrow as a source of hematopoietic cells for allogeneic transplantation. Blood, 95(12), 3702-3709.

[2] Bensinger, W.I., Clift, R., Martin, P., Appelbaum, F.R., Demirer, T., Gooley, T., Lilleby, K., Rowley, S., Sanders, J., Storb, R. and Buckner, C.D. (1996) Allogeneic peripheral blood stem cell transplantation in patients with advanced hematologic malignancies: A retrospective comparison with marrow transplantation. Blood, 88(7), 2794-2800.

[3] Smith, T.J., Hillner, B.E., Schmitz, N., Linch, D.C., Dreger, P., Goldstone, A.H., Boogaerts, M.A., Ferrant, A., Link, H., Zander, A., Yanovich, S., Kitchin, R. and Erder, M.H. (1997) Economic analysis of a randomized clinical trial to compare filgrastrim-mobilized peripheral-blood progenitor cell transplantation and autologous bone marrow transplantation in patients with Hodgkin's and nonHodgkin's lymphoma. Journal of Clinical Oncolology, 15(1), 5-10.

[4] Beyer, J., Schwella, N., Zingsem, J., Strohscheer, I., Schwaner, I., Oettle, H., Serke, S., Huhn, D. and Siegert, W. (1995) Hematopoietic rescue after high-dose chemotherapy using autologous peripheral-blood progenitor cells or bone marrow: A randomized comparison. Journal of Clinical Oncolology, 13(6), 1328-1335.

[5] Hartmann, O., Le Corroller, A.G., Blaise, D., Michon, J., Philip, I., Norol, F., Janvier, M., Louis Pico, J., Baranzelli, M.C., Rubie, H., Coze, C., Pinna, A., Meresse, V. and
Benhamou, E. (1997) Peripheral blood stem cell and bone marrow transplantation for solid tumors and lymphomas: Hematologic recovery and costs - a randomized, controlled trial. Annals of Internal Medicine, 126(8), 600-607.

[6] Schmitz, N., Linch, D.C., Dreger, P., Goldstone, A.H., Boogaerts, M.A., Ferrant, A., Demuynck, H.M., Link, H., Zander, A. and Barge, A. (1996) Randomised trial of filgrastim-mobilised peripheral blood progenitor cell transplant- tation versus autologous bone-marrow transplantation in lymphoma patients. Lancet, 347(8998), 353-357.

[7] Cutler, C. and Antin, J.H. (2001) Peripheral blood stem cells for allogeneic transplantation: A review. Stem Cells, 19(2), 108-117.

[8] Sutherland, H.J., Hogge, D.E., Landsdorp, P.M., Phillips, G.L., Eaves, A.C. and Eaves, C.J. (1995) Quantitation, mobilization, and clinical use of long-term culture-initiating cells in blood cell autografts. Journal of Hematotherapy, 4(1), 3-10.

[9] Siena, S., Schiavo, R., Pedrazzoli, P. and Carlo-Stella, C. (2000) Therapeutic relevance of CD34 cell dose in blood cell transplantation for cancer therapy. Journal of Clinical Oncolology, 18(6), 1360-1377.

[10] Keeney, M., Chin-Yee, I., Weir, K., Popma, J., Nayar, R. and Sutherland, D.R. (1998) Single platform flow cytometric absolute $\mathrm{CD}^{+} 4^{+}$cell counts based on the ISHAGE guidelines. International Society of Hematotherapy and Graft Engineering. Cytometry, 34(2), 61-70.

[11] Katsares, V., Petsa, A., Felesakis, A., Paparidis, Z., Nikolaidou, E., Gargani, S., Karvounidou, I., Ardelean, K.A., Grigoriadis, N. and Grigoriadis, J. (2009) A rapid and accurate method for the stem cell viability evaluation. The case of the thawed umbilical cord blood. Lab Medicine, 40(9), 557-560.

[12] Makino, S., Harada, M., Akashi, K., Taniguchi, S., Shibuya, T., Inaba, S. and Niho, Y. (1991) A simplified method for cryopreservation of peripheral blood stem cells at $-80^{\circ} \mathrm{C}$ without rate-controlled freezing. Bone Marrow Transplantation, 8(4), 239-244.

[13] Bakken, A.M. (2006) Cryopreserving Human Peripheral Blood Progenitor Cells. Current Stem Cell Research \& Therapy, 1(1), 47-54.

[14] Tarasov, A.I., Petrenko, A.Y. and Jones, D.R. (2004) The osmotic characteristics of human fetal liver-derived hematopoietic stem cell candidates. Cryobiology, 48(3), 333-340.

[15] Lewis, J.P., Passovoy, M., Conti, S.A., McFate, P.A., Trobaugh, F.E. (1967) The effect of cooling regimens on the transplantation potential of marrow. Transfusion, 7(1), 17-32.

[16] Meryman, H.T., Williams, R.J. and Douglas, M.S. (1977) Freezing injury from "solution effects" and its prevention by natural or artificial cryoprotection. Cryobiology, 14(3), 287-302.

[17] Cilloni, D., Garau, D., Regazzi, E., Sammarelli, G., Savoldo, B., Caramatti, C., Mangoni, L., Rizzoli, V. and Carlo-Stella, C. (1999) Primitive hematopoietic progenitors within mobilized blood are spared by uncontrolled rate freezing. Bone Marrow Transplantation, 23(5), 497503.

[18] Halle, P., Tournilhac, O., Knopinska-Posluszny, W., Justyna, K., Gembara, P., Boiret, N., Rapatel, C., Berger, 
M., Travade, P., Angielski, S., Bonhomme, J. and Déocq, F. (2001) Uncontrolled-rate freezing and storage at -80 ${ }^{0} \mathrm{C}$, with only $3.5 \%$ DMSO in cryoprotective solution for 109 autologous peripheral blood progenitor cell transplantations. Transfusion, 41(5), 667-673.

[19] Katayama, Y., Yano, T., Bessho, A., Deguchi, S., Sunami, K., Mahmut, N., Shinagawa, K., Omoto, E., Makino, S., Miyamoto, T., Mizuno, S., Fukuda, T., Eto, T., Fujisaki, T., Ohno, Y., Inaba, S., Niho, Y. and Harada, M. (1997) The effects of a simplified method for cryopreservation and thawing procedures on peripheral blood stem cells. Bone Marrow Transplantation, 19(3), 283-287.

[20] Perez-Oteyza, J., Bornstein, R., Corral, M., Hermosa, V., Alegre, A., Torrabadella, M., Ramos, P., Garcia, J., Odriozola, J. and Navarro, J.L. (1998) Controlled-rate versus uncontrolled-rate cryopreservation of peripheral blood progenitor cells: A prospective multicenter study. Group for cryobiology and biology of bone marrow transplantation (CBTNO), Spain. Haematologica, 83(11), 1001-1005.

[21] Paczkowska, E. (2002) Freezing of umbilical blood cells in mechanical freezers $\left(-80^{\circ} \mathrm{C}\right)$. Annales Academiae Medicae Stetinensis, 48, 117-133.

[22] Walter, Z., Szostek, M., Weglarska, D., Raguszewska, D., Jabłoński, M., Lorenz, F. and Skotnicki, A.B. (1999) Methods for freezing, thawing and viability estimation of hemopoietic stem cells. Przeglad Lekarski, 56(Suppl 1), 34-39.

[23] Goldman, J.M., Th'ng, K.H., Park, D.S., Spiers, A.S., Lowenthal, R.M. and Ruutu, T. (1978) Collection, cryopreservation and subsequent viability of haemopoietic stem cells intended for treatment of chronic granulocytic leukaemia in blast-cell transformation. British Journal of Haematology, 40(2), 185-195.

[24] Liseth, K., Ersvær, E., Abrahamsen, J.F., Nesthus, I., Ryningen, A., and Bruserud, Ø. (2009) Long-term cryopreservation of autologous stem cell grafts: A clinical and experimental study of hematopoietic and immunocompetent cells. Transfusion, 49(8), 1709-1719.

[25] Akkök, Ç.A., Holte, M.R., Tangen, J.M., Østenstad, B. and Bruserud, Ø. (2009) Hematopoietic engraftment of dimethyl sulfoxide-depleted autologous peripheral blood progenitor cells. Transfusion, 49(2), 354-361.

[26] Rollig, C., Babatz, J., Wagner, I., Maiwald, A., Schwarze, V., Ehninger, G. and Bornhäuser, M. (2002) Thawing of cryopreserved mobilized peripheral blood-comparison between water bath and dry warming device. Cytotherapy, 4(6), 551-555.

[27] Mavroudis, D., Read, E., Cottler-Fox, M., Couriel, D., Molldrem, J., Carter, C., Yu, M., Dunbar, C. and Barrett, J. (1996) CD34 ${ }^{+}$cell dose predicts survival, posttransplant morbidity, and rate of hematologic recovery after allogeneic marrow transplants for hematologic malignancies. Blood, 88(8), 3223-3229.

[28] Miflin, G., Russell, N.H., Hutchinson, R.M., Morgan, G., Potter, M., Pagliuca, A., Marsh, J., Bell, A., Milligan, D., Lumley, M., Cook, G. and Franklin, I. (1997) Allogeneic peripheral blood stem cell transplantation for haematological malignancies - an analysis of kinetics of engraftment and GVHD risk. Bone Marrow Transplantation, 19(1), 9-13.

[29] Shpall, E.J., Champlin, R. and Glaspy, J.A. (1998) Effect of CD34+ peripheral blood progenitor cell dose on hematopoietic recovery. Biology of Blood and Marrow Transplantation, 4(2), 84-92.

[30] Vij, R., Brown, R., Shenoy, S., Haug, J.S., Kaesberg, D., Adkins, D., Goodnough, L.T., Khoury, H. and DiPersio, J. (2000) Allogeneic peripheral blood stem cell transplantation following CD34+ enrichment by density gradient separation. Bone Marrow Transplantation, 25(12), 12231228.

[31] McGlave, P.B., De Fabritiis, P., Deisseroth, A., Goldman, J., Barnett, M., Reiffers, J., Simonsson, B., Carella, A. and Aeppli, D. (1994) Autologous transplants for chronic myelogenous leukaemia: results from eight transplant groups. Lancet, 343(8911), 1486-1488.

[32] Reiffers, J., Goldman, J., Meloni, G., Cahn, J.Y. and Gratwohl, A. (1994) On behalf of the Chronic Leukemia Working Party of the EBMT. Autologous stem cell transplantation in chronic myelogenous leukemia: A retrospective analysis of the European Group for Bone Marrow Transplantation. Bone Marrow Transplantation, 14 (3), 407-410.

[33] Burnett, A.K., Goldstone, A.H., Stevens, R.M., Hann. I.M., Rees, J.K., Gray, R.G. and Whealtley, K. (1998) Randomised comparison of addition of autologous bonemarrow transplantation to intensive chemotherapy for acute myeloid leukaemia in first remission: results of MRC AML 10 trial. Lancet, 351(9104), 700-708.

[34] De Witte, T., Van Biezen, A., Hermans, J., Labopin, M., Runde, V., Or, R., Meloni, G., Mauri, S.B., Carella, A., Apperley, J., Gratwohl, A. and Laporte, J.P. (1997) Autologous bone marrow transplantation for patients with myelodysplastic syndrome (MDS) or acute myeloid leu kemia following MDS. Blood, 90(10), 3853-3857.

[35] Harousseau, J.L., Cahn, J.Y., Pignon, B., Witz, F., Milpied, N., Delain, M., Lioure, B., Lamy, T., Desablens, B., Guilhot, F., Caillot, D., Abgrall, J.F., Francois, S., Briere, J., Guyotat, D., Casassus, P., Audhuy, B., Tellier, Z., Hurteloup, P. and Herve, P. (1997) Comparison of autologous bone marrow transplantation and intensive chemotherapy as postremission therapy in adult acute myeloid leukemia. Blood, 90(8), 2978-2986.

[36] Niwa, A., Umeda, K., Awaya, T., Yui, Y., Matsubara, H., Hiramatsu, H., Watanabe, K.I., Adachi, S., Takashi, I., Shinji, U. and Tatsutoshi N. (2009) Successful autologous peripheral blood stem cell transplantation with a double-conditioning regimen for recurrent hepatoblastoma after liver transplantation. Pediatric Transplantation, 13(2), 259-262.

[37] Nevskaya, T., Ananieva, L., Bykovskaia, S., Eremin, I., Karandashov, E., Khrennikov, J., Mach, E., Zaprjagaeva, M., Guseva, N. and Nassonov, E. (2009) Autologous progenitor cell implantation as a novel therapeutic intervenetion for ischaemic digits in systemic sclerosis. Rheuma tology, 48(1), 61-64.

[38] Mishra, V., Andresen, S., Brinch, L., Kvaløy, S., Ernst, P., Lønset, M.K., Tangen, J.M., Wikelund, J., Flatum, C., Baggerød, E., Helle, B., Vaaler, S. and Hagen, T.P. (2005) Cost of autologous peripheral blood stem cell transplanttation: the Norwegian experience from a multicenter cost study. Bone Marrow Transplantation, 35(12), 1149-1153.

[39] Van Agthoven, M., Vellenga, E., Fibbe, W.E., Kingma, T. and De Groot, C.A.U. (2001) Cost analysis and quality of 
life assessment comparing patients undergoing autologous peripheral blood stem cell transplantation or autologous bone marrow transplantation for refractory or relapsed non-Hodgkin's lymphoma or Hodgkin's disease: A prospective randomised trial. European Journal of Cancer, 37(14), 1781-1789.

[40] Ghosh, K., Gosavi, S., Pathare, A., Madkaikar, M., Rao, V.B. and Mohanty, D. (2002) Low cost autologous peripheral blood stem cell transplantation performed in a municipal hospital for a patient with plasma cell leukaemia. Clinical and Laboratory Haematology, 24(3), 187190.

[41] Reich-Slotky, R., Colovai, A.I., Semidei-Pomales, M., Patel, N., Cairo, M., Jhang, J. and Schwartz, J. (2008) Determining post-thaw CD34+ cell dose of cryopreserved haematopoietic progenitor cells demonstrates high recovery and confirms their integrity. Vox Sanguinis, 94 (4), 351-357.

[42] Haas, R., Witt, B., Goldschmidt, H., Hohaus, S., Fruehauf, S., Wannenmacher, M. and Hunstein, W. (1995) Sustained long-term hematopoiesis after myeloablative therapy with peripheral blood progenitor cell support. Blood, 85(12), 3754-3761.

[43] Ketterer, N., Salles, G., Raba, M., Espinouse, D., Sonet, A., Tremisi, P., Dumontet, C., Moullet, I., Eljaafari-Corbin, A., Neidhardt-Berard, E.-M., Bouafia, F. and Coiffier, B. (1998) High CD34 ${ }^{+}$cell counts decrease hematologic toxicity of autologous peripheral blood progenitor cell transplantation. Blood, 91(9), 3148-3155.

[44] Bittencourt, H., Rocha, V., Chevret, S., Socie, G., Esperou, H., Devergie, A., Dal Cortivo, L., Marolleau, J-P., Garnier, F., Ribaud, P. and Gluckman, E. (2002) Association of CD34 cell dose with hematopoietic recovery, infections, and other outcomes after HLA-identical sibling bone marrow transplantation. Blood, 99(8), 2726-2733.

[45] De Lima, M., McMannis, J., Gee, A., Komanduri, K., Couriel, D., Andersson, B.S., Hosing, C., Khouri, I., Jones, R., Champlin, R., Karandish, S., Sadeghi, T., Peled, T., Grynspan, F., Daniely, Y., Nagler, A. and Shpall, E.J. (2008) Transplantation of ex vivo expanded cord blood cells using the copper chelator tetraethyllenepentamine: A phase I/II clinical trial. Bone Marrow Transplantation, 41(9), 771-778.

[46] Briddell, R.A., Kern, B.P., Zilm, K.L., Stoney, G.B. and McNiece, I.K. (1997) Purification of CD34 $4^{+}$cells is essential for optimal ex vivo expansion of umbilical cord blood cells. Journal of Hematotherapy, 6(2), 145-150.

[47] Laroche, V., McKenna, D.H., Moroff, G., Schierman, T., Kadidlo, D. and McCullough, J. (2005) Cell loss and recovery in umbilical cord blood processing: A comparison of postthaw and postwash samples. Transfusion, 45(12), 1909-1916.

[48] El Beshlawy, A., Metwally, H.G., El Khalek, K.A., Zayed, R.A., Hammoud, R.F. and Mousa, S.M. (2009) The effect of freezing on the recovery and expansion of umbilical cord blood hematopoietic stem cells. Experimental and Clinical Transplantation, 7(1), 50-55.

[49] Rossmanith, T., Schröder, B., Bug, G., Müller, P., Klenner, T., Knaus, R., Hoelzer, D. and Ottmann O.G. (2001) Interleukin 3 improves the ex vivo expansion of primitive human cord blood progenitor cells and maintains the engraftment potential of SCID repopulating cells. Stem
Cells, 19(4), 313-320.

[50] Yang, H., Zhao, H., Acker, J.P., Liu, J.Z., Akabutu, J. and McGann, L.E. (2005) Effect of dimethyl sulfoxide on post-thaw viability assessment of $\mathrm{CD}_{4} 5^{+}$and $\mathrm{CD} 34^{+}$ cells of umbilical cord blood and mobilized peripheral blood. Cryobiology, 51(2), 165-175.

[51] Moezzi, L., Pourfathollah, A.A., Alimoghaddam, K., Soleimani, M. and Ardjmand A. (2005) The effect of cryopreservation on clonogenic capacity and in vitro expansion potential of umbilical cord blood progenitor cells. Transplant Proceedings, 37(10), 4500-4503.

[52] McNiece, I., Jones, R., Cagnoni, P., Bearman, S., Nieto, Y. and Shpall, E.J. (1999) Ex vivo expansion of hematopoietic progenitor cells: Preliminary results in breast cancer. Hematological Cellular Therapy, 41(2), 82-86.

[53] Koller, M.R., Manchel, I., Maher, R.J., Goltry, K.L., Armstrong, R.D. and Smith, A.K. (1998) Clinical-scale human umbilical cord blood cell expansion in a novel automated perfusion culture system. Bone Marrow Transplantation, 21(7), 653-663.

[54] Piacibello, W., Gammaitoni, L., Bruno, S., Gunetti, M., Fagioli, F., Cavalloni, G. and Aglietta, M. (2000) Negative influence of IL3 on the expansion of human cord blood in vivo long-term repopulating stem cells. Journal of Hematotherapy \& Stem Cell Research, 9(6), 945-956.

[55] Henon, P., Sovalat, H., Becker, M., Arkam, Y., OjedaUribe, M., Raidot, J.P., Husseini, F., Wunder, E., Bourderont, D. and Audhuy, B. (1998) Primordial role of $\mathrm{CD} 34^{+} / 38^{-}$cells in early and late trilineage haemopoietic engraftment after autologous blood cell transplantation. British Journal Haematology, 103(2), 568-581.

[56] Henon, P.H., Sovalat, H. and Bourderont, D. (2001) Importance of $\mathrm{CD} 34^{+}$cell subsets in autologous PBSC trans-plantation: The mulhouse experience using CD34 ${ }^{+}$. Journal of Biological Regulators and Homeostatic Agents, 15, 62-67.

[57] Ishikawa, F., Livingston, A.G., Minamiguchi, H., Wingard, J.R. and Ogawa, M., (2003) Human cord blood long-term engrafting cells are $\mathrm{CD} 34^{+} \mathrm{CD} 38^{-}$. Leukemia, 17(5), 960-964.

[58] Peled, T., Mandel, J., Goudsmid, R.N., Landor, C., Hasson, N., Harati, D., Austin, M., Hasson, A., Fibach, E., Shpall, E.J. and Nagler, A. (2004) Pre-clinical development of cord blood-derived progenitor cell graft expanded ex vivo with cytokines and the polyamine copper chelator tetraethylenepentamine. Cytotherapy, 6(4), 344355.

[59] Lam, A.C., Li, K., Zhang, X.B., Li, C.K., Fok, T.F., Chang, A.M.Z., James, A.E., Tsang, K.S. and Yuen, M.P. (2001) Preclinical ex vivo expansion of cord blood hematopoietic stem and progenitor cells: Duration of culture; the media, serum supplements, and growth factors used and engraftment in NOD/SCID mice. Transfusion, 41 (12), 1567-1576.

[60] Kögler, G., Nürnberger, W., Fischer, J., Niehues, T., Somville, T., Göbel, U. and Wernet, P. (1999) Simultaneous cord blood transplantation of ex vivo expanded together with non-expanded cells for high risk leukemia. Bone Marrow Transplantation, 24(4), 397-403.

[61] Bertolini, F., Battaglia, M., Pedrazzoli, P., Prada, G.D., Lanza, A., Soligo, D., Caneva, L., Sarina, B., Murphy, S., Thomas, T. and Della Cuna, G.R. (1997) Megakaryocytic 
progenitors can be generated ex vivo and safely administered to autologous peripheral blood progenitor cell transplant recipients. Blood, 89(8), 2679-2688.

[62] Williams, S.F., Lee, W.J., Bender, J.G., Zimmerman, T., Swinney, P., Blake, M., Carreon, J., Schilling, M., Smith, S., Williams, D.E., Oldham, F. and Van Epps D. (1996) Selection and expansion of peripheral blood CD34+ cells in autologous stem cell transplantation for breast cancer. Blood, 87(5), 1687-1691.

[63] Stiff, P., Chen, B., Franklin, W., Oldenberg, D., Hsi, E., Bayer, R., Shpall, E., Douville, J., Mandalam, R., Malhotra, D., Muller, T., Armstrong, R.D. and Smith A. (2000) Autologous transplantation of ex vivo expanded bone marrow cells grown from small aliquots after high-dose chemotherapy for breast cancer. Blood, 95(6), 2169-2174.

[64] Ruggieri, L., Heimfeld, S. and Broxmeyer, H.E. (1994) Cytokine-dependent ex vivo expansion of early subsets of CD $34^{+}$cord blood myeloid progenitors is enhanced by cord blood plasma, but expansion of the more mature subsets of progenitors is favored. Blood Cells, 20(2-3), 436-454.

[65] Bertolini, F., Lazzari, L., Lauri, E., Corsini, C. and Sirchia, G. (1994) Cord blood plasma mediated ex vivo expansion of hematopoietic progenitor cells. Bone Marrow Transplantation, 14(3), 347-353.

[66] Li, N., Feugier, P., Serrurrier, B., Latger-Cannard, V., Lesesve, J.F., Stoltz, J.F. and Eljaafari, A. (2007) Human mesenchymal stem cells improve ex vivo expansion of adult human $\mathrm{CD} 34^{+}$peripheral blood progenitor cells and decrease their allostimulatory capacity. Experimental Hematology, 35(3), 507-515.

[67] Devine, S.M. (2002) Mesenchymal stem cells: Will they have a role in the clinic? Journal of Cellular Biochemistry-Supplement, 28, 73-79.

[68] Deans, R.J. and Moseley, A.B. (2000) Mesenchymal stem cells: Biology and potential clinical uses. Experimental Hematology, 28(8), 875-884.

[69] Kadereit, S., Deeds, L.S., Haynesworth, S.E., Koc, O.N., Kozik, M.M., Szekely, E., Daum-Woods, K., Goetchius, G.W., Fu, P., Welniak, L.A., Murphy, W.J. and Laughlin, M.J. (2002) Expansion of LTC-ICs and maintenance of p21 and BCL-2 expression in cord blood CD $34^{+} / \mathrm{CD} 38^{-}$ early progenitors cultured over human MSCs as a feeder layer. Stem Cells, 20(6), 573-582.

[70] Koh, S.H., Choi, H.S., Park, E.S., Kang, H.J., Ahn, H.S. and Shin, H.Y. (2005) Co-culture of human CD34 $4^{+}$cells with mesenchymal stem cells increases the survival of $\mathrm{CD}^{+} 4^{+}$cells against the 5 -aza-deoxycytidine-or trichostatin A-induced cell death. Biochemical and Biophysical Research Communications, 329(3), 1039-1045.

[71] Bennaceur-Griscelli, A., Pondarre, C., Schiavon, V., Vainchenker, W. and Coulombel, L. (2001) Stromal cells retard the differentiation of $\mathrm{CD} 34^{+} / \mathrm{CD} 38^{\text {low/neg }}$ human primitive progenitors exposed to cytokines independent of their mitotic history. Blood, 97(2), 435-441.

[72] Liu, Y., Liu, T. , Fan, X., Ma, X. and Cui, Z. (2006) Ex vivo expansion of hematopoietic stem cells derived from umbilical cord blood in rotating wall vessel. Journal of Biotechnology, 124(3), 592-601.

[73] Nielsen, L.K. (1999) Bioreactors for hematopoietic cell culture. Annual Review of Biomedical Engineering, 1(1), 129-152.

[74] Cabrita, G.J., Ferreira, B.S., da Silva, C.L., Goncalves, R., Almeida-Porada, G. and Cabral, J.M. (2003) Hematopoietic stem cells: from the bone to the bioreactor. Trends in Biotechnology, 21(5), 233-240.

[75] Cabral, J.M.S. (2001) Ex vivo expansion of hematopoietic stem cells in bioreactors. Biotechnology Letters, 23 (10), 741-751.

[76] Hammond, T.G. and Hammond, J.M. (2001) Optimized suspension culture: the rotating wall vessel. American Journal of Physiology-Renal Physiology, 281(1), F12F25.

[77] Plett, P.A., Abonour, R., Frankovitz, S.M. and Orschell, C.M. (2004) Impact of modeled microgravity on migration, differentiation, and cell cycle control of primitive human hematopoietic progenitor cells. Experimental Hematology, 32(8), 773-781.

[78] Sytkowski, A.J. and Davis, K.L. (2001) Erythroid cell growth and differentiation in vitro in the simulated microgravity environment of the NASA rotating wall vessel bioreactor. In Vitro Cellular and Developmental Biology-Animal, 37(2), 79-83.

[79] Plett, P.A., Frankovitz, S.M., Abonour, R. and OrschellTraycoff, C.M. (2001) Proliferation of human hematopoietic bone marrow cells in simulated microgravity. In Vitro Cellular and Developmental Biology-Animal, 37(2), 73-78.

[80] Martin, Y. and Vermette, P. (2005) Bioreactors for tissue mass culture: design, characterization, and recent advances. Biomaterials, 26(35), 7481-7503.

[81] Ohi, S., Roach, A.N., Ramsahai, S., Kim, B.C., Fitzgerald, W., Riley, D.A. and Gonda, S.R. (2004) The hematopoi- etic stem cell therapy for exploration of deep space. New Frontiers \& Future Concepts. AIP Conference Proceedings, 699, 938-950.

[82] Andrade-Zaldívar, H., Santos, L. and Antonio De León Rodríguez, A. (2008) Expansion of human hematopoietic stem cells for transplantation: trends and perspectives. Cytotechnology, 56(3), 151-160.

[83] Delaney, C., Heimfeld, S., Brashem-Stein, C., Voorhies, H., Manger, R.L. and Bernstein, I.D. (2010) Notch-mediated expansion of human cord blood progenitor cells capable of rapid myeloid reconstitution. Nature Medicine, 16, 232-236. 


\section{GLOSSARY OF ABBREVIATIONS AND INITIALISMS}

BM: Bone Marrow

DMSO: Dimethyl sulfoxide GVHD: Graft versus Host Disease HARV: High Aspect Ratio Vessel hESC: human Ebryonic Stem Cell HLA: Human Leukocyte Antigen
HPC: Hematopoietic Progenitor Cell HSC: Hematopoietic Stem Cell LTC-IC: Long-term culture initiating colony NASA: National Aeronautics and Space Administration PBSC: Peripheral Blood Stem Cell PBSCT: Peripheral Blood Stem Cell Transplantation PPC: Primitive progenitor cell RWV: Rotating Wall Vessel STLV: Slow Turn Lateral Vessel 